\title{
Taking It to the Streets: Figuring Out and Communicating What's Really Important in Children's Health and Well-being Research
}

\section{Sortir au grand jour : compréhension et communication de ce qui compte vraiment en matière de recherche sur la santé et le bien-être des enfants}

\author{
NORALOU P. ROOS, PHD \\ Senior Research Scientist, Manitoba Centre for Health Policy \\ University of Manitoba, Winnipeg, $M B$ \\ JANE FREEMANTLE, MPH, PHD \\ Associate Professor and Principal Research Fellow \\ Melbourne School of Population Health \\ University of Melbourne, Parkville, Australia \\ GERALD FARTHING \\ Deputy Minister - Education, Citizenship, Youth \\ Government of Manitoba, Winnipeg, MB \\ JIM CARR \\ President $\&$ CEO, Business Council of Manitoba \\ Winnipeg, $M B$
}

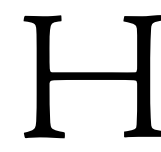

西

OW DO ACADEMICS ENSURE THAT THE ANALYSES THEY PRODUCE CAN BE accessed and understood by those in a position to use evidence to "make a difference"? This question became a concern as early findings from analyses of education data began to emerge.

In this session, Dr. Noralou Roos showed what the schools see when they review the performance of students taking grade 12 tests: $76 \%$ of those children in families receiving income assistance passed the test, compared with $96 \%$ of the students who lived in the affluent areas of the city. These results, however, report only on those who are in school, in grade 12 and writing the tests. A second graph showed the results for those who should be writing the test. We identified all children born in Manitoba who remained in Manitoba until they were 17 . Then, we determined where they were in the school system at that time (that is, during what should have been their final year in school) and identified those who had withdrawn from school. These 
data demonstrated a very different reality: only $14 \%$ of the children whose families had at some point received income assistance passed the grade 12 test on time, compared with $80 \%$ of the students living in the high SES areas who passed. Over $20 \%$ of kids from the poorest families had already withdrawn from school, and many of them had not yet made it to grade 12 .

Gerald Farthing, Deputy Minister of Manitoba Education, said that when government representatives saw the evidence on how far behind disadvantaged children were, they were startled. Although those in the ministry knew there was a relationship between low income and educational achievement, they were surprised by the strength of the relationship in their own community. Their first reaction was, "It can't be this bad," but they also understood the quality of the research. Farthing reported that the research had an impact in part because researchers had taken the time to develop a working relationship with the ministry. He emphasized that developing a relationship of trust and mutual respect between researchers and policy makers was critical. He also found it helpful that Manitoba Centre for Health Policy (MCHP) researchers made over 50 presentations to school boards, superintendents, ministry staff and others explaining the approach taken and what was found. Farthing noted that the ministry has developed policy and allocated resources, to a large degree, in directions motivated by the research.

Jim Carr, CEO of the Business Council of Manitoba, described how seeing the statistics relating educational achievement to socio-economic status led the Business Council to a social policy agenda. Understanding the evidence on school outcomes motivated Carr to accept the responsibility of becoming co-chair of the Winnipeg Poverty Reduction Council. He described how the council went to inner city schools and asked, "What are your priorities?" Council members were told the top priorities were adequate food (kids can't learn if they are hungry) and mentors. The council is now looking for a business partner to provide students with food for a full year. They have also contacted potential mentors, who responded, "When can we start?" Carr concluded that to engage others and create something people want to be part of, you must have data on the situation in reality as opposed to abstractions.

Jane Freemantle, Principal Research Fellow at the University of Melbourne, described a similar process in Australia to support targeted interventions for Aboriginal people and those living on Torres Strait Island. She demonstrated a clear example of how the analysis of linked population data could be used to engage government and community to redress inequalities in infant health among Indigenous populations. She reviewed how the Western Australian Data Linkage System was used to describe infant mortality trends, the causes of death and the context in which these deaths occurred. In particular, the data were disaggregated to identify the patterns and trends of mortality among Aboriginal compared to non-Aboriginal infants. The data were further analyzed to observe the mortality trends in deaths attributed to sudden infant death syndrome (SIDS) following a well-resourced universal intervention. While deaths attributed to SIDS declined sharply in the overall population, Aboriginal mortality rates remained significantly high, with a ninefold relative risk of death observed. These data were then used to attract substantial funding to address the persistently high rates of SIDS among Aboriginal infants. The funds were used to support targeted and culturally specific interventions in consultation with members of the Aboriginal community, NGOs and government. 